\title{
"We die only once, and for such a long time": Approaching Trauma through Translocation in Chris Abani’s Song for Night ${ }^{1}$
}

\author{
Daria Tunca \\ University of Liège, Belgium
}

I don’t know how long I die. But I think I die for very very long time. ${ }^{2}$

Many scholars in the field of postcolonial studies are familiar with the work of Chris Abani, an author of Nigerian and English parentage now living in the USA. Even though his poetic writing style and emotional subtlety enjoy wide recognition, in-depth analyses of his texts are still relatively few. This can, of course, partly be explained by the fact that his major novels and collections of poetry have only been published recently. However, it seems that this scarcity of critical studies can also be traced to the elusiveness of Abani's art, by which I mean that his works strongly resist textbook postcolonial approaches - theories which, despite their limitations, still offer interpretative avenues into much contemporary African literature of the diaspora. This is not to say that the author's books do not provide reflections on the postcolonial condition and its inherent hybridity or, in the current context of globalization, on adjacent themes such as metropolitan cosmopolitanism. These cross-cultural currents arguably form the background to his prose and poetry, and their role has been cogently underlined in existing examinations of his writing. However, while Abani himself has respectfully acknowledged the usefulness of such culturally oriented approaches, he has also stated that the principal focus of his works - his novels in particular - lies elsewhere: namely, in their exploration of "transformation."3

The entire body of Abani's fiction is indeed informed by changes in physical and

\footnotetext{
${ }^{1}$ I would like to express my gratitude to Prof. Bénédicte Ledent for her invaluable guidance and support through the multiple drafts of this article. I also wish to extend my appreciation to the participants in the "Translation and Translocation” session held at the ASNEL conference in Münster in May 2009, during which this article was first delivered - several of the panellists' helpful suggestions have found their way into the final version of this essay.

${ }^{2}$ Ken Saro-Wiwa, Sozaboy (1985; New York: Longman, 1994): 113.

${ }^{3}$ Chris Abani, reading held in the context of the "Incroci di Civiltà" series, Libreria Mondadori, Venice, Italy (29
} 
Published in: Postcolonial Translocations: Cultural Representation and Critical Spatial Thinking, ed. by Marga Munkelt, Markus Schmitz, Mark Stein \& Silke Stroh (Amsterdam \& New York: Rodopi, 2013), pp. 127-143.

Status: Postprint (Author's version)

emotional states, and, more generally, his texts are replete with crossings of concrete and abstract frontiers of all kinds. It therefore comes as no surprise that an array of concepts beginning with the prefix 'trans-' could be used to capture the gist of his narratives and, in some cases, offer interpretative leads. For instance, 'transgendering' provides one of the main motifs in The Virgin of Flames, ${ }^{4}$ which features a cross-dressing artist living in Los Angeles; 'transgression' perhaps best characterizes the protagonists' overstepping of moral boundaries in Becoming Abigail, ${ }^{5}$ the account of an adolescent Nigerian girl forced to emigrate to London; and 'translocation', as I will argue in the course of this essay, constitutes a pivotal paradigm in Song For Night, ${ }^{6}$ the story of a child soldier, set during the final days of the Biafran war, the civil conflict that divided Nigeria between 1967 and 1970.

The prefix 'trans-' evidently finds its roots in Latin, and etymologically means 'across', 'over', or 'through'. Interestingly, an analogous notion occupies a central position in the broader theoretical framework in which I wish to situate my examination of Abani's war novella: that of trauma studies, an area of investigation which has, among other things, dissected the mechanisms of working through - that is, of progressively, and often only partially, overcoming terrifying ordeals such as genocide. In its early stages, this critical movement mainly concerned itself with the repercussions and representations of the Holocaust, but in recent years its methods have been repeatedly applied to postcolonial sources. ${ }^{7}$ This encounter has encouraged scholars to develop hermeneutics better suited to the exploration of psychologically devastating experiences occurring either across civilizations or in non-Western cultural contexts.

A methodology inspired by trauma studies seems particularly relevant to the analysis of Abani's Song for Night, if only because the experiences recounted by the main character and narrator of the novella, a fifteen-year-old boy called My Luck, may be called 'traumatic' in the most widely accepted sense of the term. The many atrocities that he, both a victim and a perpetrator, either witnesses or participates in, include the murder of his Igbo mother at the

\footnotetext{
March 2008).

${ }^{4}$ Chris Abani, The Virgin of Flames (New York: Penguin, 2007).

${ }^{5}$ Chris Abani, Becoming Abigail (New York: Akashic, 2006).

${ }^{6}$ Chris Abani, Song for Night (New York: Akashic, 2007). All page references will be given in the text.

${ }^{7}$ The problems that may potentially arise from the application of a set of theories with a largely 'Western' cultural anchorage to postcolonial texts have been debated within the new movement of "postcolonial trauma studies' itself - see, for example, Stef Craps \& Gert Buelens, "Introduction: Postcolonial Trauma Novels," Studies in the Novel 40.1-2 (Spring-Summer 2008): 2-3, and Michael Rothberg, "Decolonizing Trauma Studies: A Response," Studies in the Novel 40.1-2 (Spring-Summer 2008): 227-29. While one should heed cultural generalizations, I concur with Michael Rothberg that a "tendency toward hyper-particularism” ("Decolonizing Trauma Studies," 228) whereby the application of theoretical models would be restricted to their contexts of origin may be equally counterproductive.
} 
Published in: Postcolonial Translocations: Cultural Representation and Critical Spatial Thinking, ed. by Marga Munkelt, Markus Schmitz, Mark Stein \& Silke Stroh (Amsterdam \& New York: Rodopi, 2013), pp. 127-143.

Status: Postprint (Author's version)

hands of Hausa soldiers, his accidental shooting of a seven-year-old girl, and his frenzied killing of a group of old women about to eat a dead baby. These accumulated scenes of intense violence overpower the reader and have caused some discomfort in reviewers, ${ }^{8}$ but Abani's hyperbolic strategy is by no means gratuitous, as it serves the ultimate purpose of his novella: exploring man's capacity to cross moral boundaries in extreme situations. For the writer, facing the unbearable, including taboo subjects such as cannibalism, is necessary to initiate a communal healing process, whether in Nigeria or elsewhere. The emphasis placed on the moral aspects of human experience clearly appears in the following extract from an interview, in which the author is asked to comment on the effects of the Biafran war:

In every war there is cannibalism, and nobody talks about it. One of the most amazing things that has emerged recently is tales of the concentration camps in Germany, and of how people would eat each other and not talk about it afterwards.

For me there is no subject, if we are to regain any kind of internal moral landscape, there can be nothing that is not [to] be confronted. ${ }^{9}$

This mention of the horrors of Nazi Germany in the context of a discussion of the Biafran war is not unique, but the parallel is nonetheless striking. ${ }^{10}$ Such pronouncements undeniably testify to the cross-cultural, or indeed universalist, nature of Abani's writerly commitment ${ }^{11}$ a humanistic world-view which aligns him with followers of postcolonial trauma theory, and perhaps indicates that he may share more concerns with this movement than African authors such as Chinua Achebe or Chimamanda Ngozi Adichie, who place greater emphasis on the

\footnotetext{
${ }^{8}$ For instance, Malcolm Knox lists some of the traumatizing occurrences recounted in the opening pages of the book and notes:

Such horrors have certainly befallen young soldiers in African wars, though it is unlikely that they have all happened to one. It is, of course, the novelist's liberty to concentrate many events into one life but I couldn't help asking why. Why is Abani piling all the horrors of several lives into one? What is the desired effect?
}

—Knox, "Haunted by the Ghosts in a Child Soldier’s Life,” Sydney Morning Herald (8 November 2008), www.smh.com.au/articles/2008/ll/07/1225561105879.html (accessed 5 April 2010).

${ }^{9}$ Chris Abani, “The Model of African Wars,” Voices Education Project (nd), http://voicesinwartime.org/content/ chris-abani (accessed 5 April 2010).

${ }^{10}$ A reference to Nazi Germany is also contained in Song for Night, in which the young protagonist encounters an old man playing a gramophone record of a German song that the man finds "beautiful" but which is in fact "a long slow lament for the Aryan race.” See Abani, Song for Night, 124, 125. Such passages contribute to the writer's exploration of the concepts of beauty and ugliness - a recurrent topic in Abani's fiction that would deserve to be examined in more detail.

${ }^{11}$ For a reflection on the link between the Holocaust and the "universality of the human experience" in Abani's work, see Francesca Giommi, "Negotiating Freedom on Scarred Bodies: Chris Abani's Novellas," in Experiences of Freedom in Postcolonial Literatures and Cultures, ed. Annalisa Oboe \& Shaul Bassi (Abingdon 
Published in: Postcolonial Translocations: Cultural Representation and Critical Spatial Thinking, ed. by Marga Munkelt, Markus Schmitz, Mark Stein \& Silke Stroh (Amsterdam \& New York: Rodopi, 2013), pp. 127-143.

Status: Postprint (Author's version)

divisive character of individual and collective geocultural specificities.

Above all, Abani's statement reminds us that literature has an important role to play in addressing the subject of trauma. Keenly aware of this, the writer has stated that one of his main preoccupations since his incarceration as a political prisoner in Nigeria - a harrowing experience recorded in his collection of poetry Kalakuta Republic ${ }^{12}$ - has been to "[rebuild] the language that one can use to approach trauma."13 For him, the act of working through is closely connected to that of searching for words to depict the suffering inflicted by man on his own kind. His artistic challenge therefore resides in finding the narrative and stylistic techniques best suited to broaching the delicate issue of trauma, for, as the author himself has said, "The art is never about what you write about. The art is about how you write about what you write about." 14

Whether there are appropriate ways of writing about the 'unspeakable' has been a subject of contention since at least the Second World War and Theodor Adorno's famous statement that "to write poetry after Auschwitz is barbaric." ${ }^{15}$ More recently, practitioners of trauma studies have turned their attention to the ethical challenges posed to writers, filmmakers, and historians engaged in describing the atrocities endured by others. The work of Dominick LaCapra, in particular, provides an illuminating examination of the potential difficulties faced by "secondary witnesses" in their documentation of "limit events." In his seminal book Writing History, Writing Trauma, LaCapra argues that one's response to another person's or people's traumatic experience should be marked by a form of "empathic unsettlement."16 Empathy, the author insists, "should not be conflated with unchecked identification, vicarious experience, and unchecked victimage," 17 but "should rather be understood in terms of an affective relation, rapport, or bond with the other recognized and respected as other."18 LaCapra thereby denounces the appropriation of traumatic experiences by those recording them; further, he is adamant that the accounts of extreme events and their

\footnotetext{
\& New York: Routledge, 2011): 180.

${ }^{12}$ Abani, Kalakuta Republic (London: Saqi, 2000).

${ }^{13}$ Chris Abani, in Kevin Rabalais, “The Clarity of Distance," Australian (30 August 2008), www.theaustralian.com.au/news/arts/the-clarity-of-distance/story-e6frg8n6-1111117306592 (accessed 5 April 2010).

${ }^{14}$ Chris Abani, Interview by Carlye Archibeque, Poetix (2005), http://poetix.net/abani.htm (accessed 5 April 2010).

${ }^{15}$ Theodor Adorno, "Cultural Criticism and Society,” in Adorno, Prisms, tr. Samuel Weber \& Shierry Weber ("Kulturkritik und Gesellschaft,” 1951; Cambridge MA: MIT Press, 1981): 34. However, Adorno later acknowledged that "perennial suffering has as much right to expression as the tortured have to scream." Adorno, Negative Dialectics, tr. E.B. Ashton (Negative Dialektik, 1966; New York: Continuum, 1973): 362.

${ }^{16}$ Dominick LaCapra, Writing History, Writing Trauma (Baltimore MD: Johns Hopkins UP, 2001). The phrases 'secondary witnesses', 'limit events', and 'empathic unsettlement' are used throughout the study.

${ }^{17}$ LaCapra, Writing History, Writing Trauma, 40.
} 
Published in: Postcolonial Translocations: Cultural Representation and Critical Spatial Thinking, ed. by Marga Munkelt, Markus Schmitz, Mark Stein \& Silke Stroh (Amsterdam \& New York: Rodopi, 2013), pp. 127-143.

Status: Postprint (Author's version)

aftermath should not serve as excuses to reinforce the readers' or viewers' sense of security. Thus, he maintains, narratives of trauma should remain unsettling to the very end. ${ }^{19}$

In spite of potentially normative undertones, LaCapra's theory provides valuable guiding principles. In the present essay, I will use the concept of 'empathic unsettlement' as a critical instrument to assess Abani's Song for Night and suggest that the novella can be termed a successful exploration of trauma from beginning to end. Crucially, the ways in which the writer achieves this are subtle and thus easily missed, for Abani does employ a number of techniques traditionally associated with "surrogate victimage” ${ }^{20}$ or pathos, such as first-person interior monologue or the appeal to readers' emotions. Nevertheless, the originality of his writing largely resides in his unpredictable use of these elements to introduce provocative questionings and to present an original artistic vision. I will be arguing that, in Song for Night, one such element used creatively is the concept of translocation, which not only refers to a movement from one place - whether abstract or concrete - to another, but may simultaneously denote a single site of transition and change: i.e. a 'trans-location' ${ }^{21}$ In other words, my main argument will rely on the idea that the interplay between these two meanings of 'translocation' can help us understand Abani’s fictional strategy, more particularly as it relates to the exploration of the protagonist's trauma.

In what follows, I will first of all underline the thematic ubiquity of translocation in the novella, and then endeavour to show how the book, by revealing the character's apparent movement in space to have been a 'trans-location' all along, achieves 'empathic unsettlement'. More precisely, I will try to demonstrate that Abani's substitution of one understanding of translocation for the other acts as a distancing device, either to prevent "unchecked identification" with the hero on the reader's part or to bypass the danger of providing a "harmonizing narrative." The writer's skilful and versatile use of translocation allows him to lay the foundation for his examination of the same concept in another, more abstract form: the passage from traumatic experience to language, a link touched upon earlier in this essay in relation to Abani's conception of writing as a way of articulating trauma. By

\footnotetext{
${ }^{18}$ Writing History, Writing Trauma, 212-13.

${ }^{19}$ LaCapra is critical of what he perceives as the impropriety of "harmonizing narratives that provid[e] the reader or viewer with an unwarranted sense of spiritual lift" (Writing History, Writing Trauma, 14). In his discussion, the author suggests, for instance, that the ending of Steven Spielberg's Schindler's List turns the film into such a "harmonizing" or "redemptive" narrative.

${ }^{20}$ Writing History, Writing Trauma, 40.

${ }^{21}$ I owe this distinction to the editors of the present volume, who suggested a somewhat similar double definition in the call for papers for the 2009 ASNEL conference. For the purpose of clarity, my use of 'translocation' will henceforth refer to the term in its double meaning; 'translocation as a single site' will be rendered with the hyphenated spelling 'trans-location', while translocation as the transfer from one locale to the next will be
} 
Published in: Postcolonial Translocations: Cultural Representation and Critical Spatial Thinking, ed. by Marga Munkelt, Markus Schmitz, Mark Stein \& Silke Stroh (Amsterdam \& New York: Rodopi, 2013), pp. 127-143.

Status: Postprint (Author's version)

way of conclusion, I will briefly comment on how the author's representation of trauma in Song for Night may be understood in the context of his entire artistic project.

Translocation is a pervasive motif in Abani's novella, starting with its two epigraphs. Taking as a point of departure a narrower, culturally related avatar of the concept (arguably the default mode in postcolonial studies), one may rapidly conclude that Song for Night's paratextual elements situate this work at a cross-cultural crossroads. Indeed, while the story is that of a young soldier during the Biafran war, neither of the introductory quotations belongs to the African literary tradition. Interestingly, however, neither of the epigraphs is borrowed from the canon of the former British imperial centre, either, since the first is from a work by the seventeenth-century French playwright Molière, while the second comes from a book by the controversial twentieth-century US-Peruvian author Carlos Castaneda. ${ }^{22}$ This eclectic literary genealogy may leave postcolonial critics somewhat puzzled, which only emphasizes the need for them to discard traditional counter-discursive approaches - or even temporarily leave aside political and cultural considerations altogether - and envisage a more open reading of these excerpts and of the novel at large.

A brief examination of the quotations' metaphoric qualities reveals that both passages deal with travelling. ${ }^{23}$ The extract from Castaneda's work reads "on any path that may have heart. There I travel,” while the passage from Molière, borrowed for the title of this essay, reflects on the ultimate journey: i.e. death. Importantly, the English version of Molière's statement, unlike the French original, ${ }^{24}$ is ambiguous, since dying 'for a long time' can mean either that the state of death is eternal (the French playwright's actual suggestion) or that the process of dying is very slow. ${ }^{25}$ This possible 'misreading' of Molière's assertion provides one of the keys to the interpretation of Abani's novella, for, as I will now briefly show, the

designated by the terms 'translocation-as-movement' or 'translocation-as-journey'.

${ }^{22}$ The extract is part of an epigraph cited by Castaneda (in both Spanish and English) in one of his works, and attributed to the Amerindian shaman Don Juan Matus. See Carlos Castaneda, The Teachings of Don Juan: A Yaqui Way of Knowledge (1969: Berkeley \& Los Angeles: U of California P, 1998): xx. It is now widely accepted that Don Juan was in fact a fictional figure created by Castaneda in his 1969 book. The questions surrounding the frontier between fact and fiction raised in the figure of Don Juan may partly have motivated Abani's choice of this quotation for, as will shortly become apparent, the blurring between the realms of reality and illusion plays a central role in Song for Night. For an overview of the controversy surrounding Castaneda and his work, see, for example, Robert Marshall, "The Dark Legacy of Carlos Castaneda," salon.com (4 April 2007), www.salon.com/books/feature/2007/04/12/castaneda (accessed 5 April 2010).

${ }^{23}$ Proponents of culturally based approaches may legitimately argue that diasporic authors are more likely than other writers to use the theme of travelling as a metaphor, considering that displacement is at the heart of their condition. However, my suggestion will be that the notion of travelling as it appears here seems to have more markedly metaphysical undertones than it does in most diasporic writing.

24 “On ne meurt qu'une fois, et c'est pour si longtemps !" See Molière, Le Dépit amoureux (1656), Euvres de Molière 1, éd. Eugène Despois (Paris: Hachette, 1873): Act V, Scene 4.

${ }^{25}$ This interpretation may be assigned to my epigraph from Saro-Wiwa's Sozaboy. It should nevertheless be noted that, in Saro-Wiwa's novel, the narrator is not literally dying but falling asleep while wounded. 
Published in: Postcolonial Translocations: Cultural Representation and Critical Spatial Thinking, ed. by Marga Munkelt, Markus Schmitz, Mark Stein \& Silke Stroh (Amsterdam \& New York: Rodopi, 2013), pp. 127-143.

Status: Postprint (Author's version)

book's narrative strategy rests largely on the idea that death can be regarded as a long journey.

Song for Night opens as My Luck, who has been working as a mine diffuser for three years, regains consciousness after an explosion and is unable to locate his fighting unit. The narrative proceeds as follows:

The rule of thumb is that if you hear the explosion, you survived the blast. [...] I heard the click and I heard the explosion even though I was lifted into the air. [...] When I came to, everyone was gone. They must have thought I was dead and so set off without me [...].

Stupid fools. Wait until I catch up with them. (22)

The average reader is unlikely to question the narrator's statement, and will most probably assume that, since My Luck has "hear[d] the explosion," he has really "survived the blast.” A greater level of attentiveness is required to notice that the logic of this argument is fundamentally flawed, for the young soldiers cannot possibly know whether those who died did not hear the explosion too. And, indeed, as the story progresses and one strange occurrence follows on from another, the suspicion gradually dawns that My Luck might be hallucinating and, at the very end of the novella, the reader acquires the certainty that the narrator's search for his lost comrades, depicted throughout the story, was in fact an imaginary march towards death. Of course, the use of the journey to conceptualize the passage into death is not unique to Abani. It brings to mind sources as varied as the river Styx in Greek mythology, ${ }^{26}$ the Bible's twenty-third psalm, and the hero's trip to "Deads' Town” in Amos Tutuola's The Palm-Wine Drinkard. ${ }^{27}$ At this point, one might easily dismiss Abani's narrative as yet another variation on a well-known trope, if not for the fact that the writer defies expectations by narrating a journey which unsuspecting readers do not straight away identify as being anything but physical. What one initially assumes to be a movement in space turns out to be an experience situated at a single 'trans-location': the boundary between life and death. In other words, Abani's novella problematizes the concept of translocation-asjourney in order to explore the many forces at work in the transitions between different realms.

One such transition treated in Song for Night is the transposition of reality into language. As will gradually become apparent, this transfer may, in a manner similar to death,

\footnotetext{
${ }^{26}$ Significantly, My Luck also encounters a river towards the end of the story. That "the river slowly takes on the metaphorical weight of the Styx" was remarked upon by Nicole Gluckstern ("Shorts," San Francisco Bay Guardian Online [25 September 2007], www.sfbg.com/2007/09/25/shorts (accessed 5 April 2010)).

${ }^{27}$ Amos Tutuola, The Palm-Wine Drinkard (London: Faber \& Faber, 1952).
} 
Published in: Postcolonial Translocations: Cultural Representation and Critical Spatial Thinking, ed. by Marga Munkelt, Markus Schmitz, Mark Stein \& Silke Stroh (Amsterdam \& New York: Rodopi, 2013), pp. 127-143.

Status: Postprint (Author's version)

be perceived both as a figurative translocation-as-movement and as a trans-location: on the one hand, the linguistic articulation of events involves a progressive passage from experience to expression; on the other, the only empirically observable trace of this process is the translocation in which it is recorded: i.e. the site of language itself. At first glance, the protagonist's journey towards death and his attempt to relate his painful experiences under the author's guiding hand may appear only tenuously linked, but they are in fact two sides of the same coin, for both can be considered as steps in the character's slow coming to terms with trauma. If the former type of translocation - the apparent movement in space - effects My Luck's gradual reconciliation with death, ${ }^{28}$ the latter - the articulation of his ordeal - helps him to probe his psychological wounds. Importantly, however, the novella does not draw a simplistic equation between the victim-cum-perpetrator's voicing of trauma and the act of working through, as might be the case in a "harmonizing narrative" providing a reassuring sense of closure. One way in which the text avoids this pitfall is by means of self-reflexive narrative gestures.

Indeed, from the very beginning, the book draws attention to its own fictional quality. The powerful opening sentences of the novella are a case in point, as they establish that My Luck is mute, and therefore technically unable to address the reader orally as he does: "What you hear is not my voice. I have not spoken in three years” (19). Readers are asked to believe that the words they are 'hearing' are the narrator's 'thoughts', which are further identified as renditions in English of his mental reflections in his Igbo mother tongue: "You are in fact hearing my thoughts in Igbo" (21). Addressees are thus forced to suspend their disbelief and adhere to a parallel reality that does not obey the laws of the 'real' world. The immersion in this alternative universe only reinforces the sense of shock experienced when the reason behind My Luck's muteness is revealed. He reports that, when he was in boot camp, a doctor "severed" his and his comrades" "vocal chords," so that, if one of the young soldiers should be "blown up by a mine," the others would not be scared by their friend's "death screams" (35). But this brutal silencing has not had the intended effect, since the narrator adds that "in the silence of our heads, the screams of those dying around us were louder than if they still had their voices" (35). From the onset, then, the text establishes the existence of two levels of reality: one is an 'objective', outside realm in which the mute hero and his friends cannot communicate verbally with each other and with the world; the other is an inner, imaginary

\footnotetext{
${ }^{28}$ According to Abani, the narrator eventually "ma[kes] peace with death." See Chris Abani, "Ethics and Narrative: The Human and Other,” Witness 22 (2009), http: //witness.blackmountaininstitute.org/archive/xxii/Witness_ XXII-Abani.pdf (accessed 5 April 2010): 172.
} 
Published in: Postcolonial Translocations: Cultural Representation and Critical Spatial Thinking, ed. by Marga Munkelt, Markus Schmitz, Mark Stein \& Silke Stroh (Amsterdam \& New York: Rodopi, 2013), pp. 127-143.

Status: Postprint (Author's version)

sphere in which My Luck tells his story and can hear his friends' thoughts and feelings. This step back from mimetic realism certainly acts as a safeguard against any 'unchecked identification' on the part of the reader; put differently, one of the ways in which the beginning of the novella achieves 'empathic unsettlement' is by forcing readers to engage with the mechanisms of fictional representation.

In addition to this key metafictional function, the protagonist's inability to speak has deep symbolic significance, too, as it may be said to stand for the metaphorical voicelessness of all casualties of history. Figurative speechlessness is a well-known symbol for political and social oppression in postcolonial studies - as suggested by the famous example of Gayatri Chakravorty Spivak’s “Can the Subaltern Speak?"29 - but once again Abani’s use of a familiar trope goes well beyond the received acceptation of the notion by postcolonial scholars, for his hero's muteness may be perceived as a compelling questioning of the ability assigned to conventional language to express human experience. More than once, My Luck's words fall short of being able to convey the horror of the situation which he vividly summons in his memory. For instance, during the ethnic troubles that lead to the war, he witnesses the brutal killing of his mother while he is hiding in a narrow space in the ceiling, and reports the events - or, rather, fails to describe them - in the following words:

Below me it happens, it happens that night bright as day, but I cannot name it, those things that happened while I watched, and I cannot speak something that was never in words, speak of things I cannot imagine, could never have seen even as I saw it. (43)

My Luck is unable to appropriately translate into words the traumatic occurrences that his imagination is unable to grasp. The limits of verbal communication are similarly emphasized when the narrator attends to his dying girlfriend Ijeoma after she has been severely mutilated by an explosion:

She [...] wasn't much more than a bloody torso, lacerated by shrapnel, body parts scattered in a way that cannot be explained or described. Instead I read her mind, or her eyes, or something, and understood everything - what she wanted, what she regretted all of it. (54, my emphasis)

\footnotetext{
${ }^{29}$ Gayatri Chakravorty Spivak, "Can the Subaltern Speak?,” in Marxism and the Interpretation of Culture, ed. Cary Nelson \& Lawrence Grossberg (Urbana \& Chicago: U of Illinois P, 1988): 271-313.
} 
Published in: Postcolonial Translocations: Cultural Representation and Critical Spatial Thinking, ed. by Marga Munkelt, Markus Schmitz, Mark Stein \& Silke Stroh (Amsterdam \& New York: Rodopi, 2013), pp. 127-143.

Status: Postprint (Author's version)

For My Luck, Ijeoma's suffering is unspeakable - he can neither find words to describe her physical state nor communicate with her using the allegedly "crude” (130) sign language that the young soldiers have developed to compensate for their muteness. The only medium that seems capable of connecting the two characters and of leading to some form of comprehension is a spiritual link based on visual contact. This imaginary translation of trauma into impalpable units of meaning involves another (figurative) form of translocation-asmovement, from the visual to the mental realm, and epitomizes the character's constant struggle with language.

That My Luck should be unable to capture his experience using traditional language even in his imaginary narration has wide-ranging ramifications. While I agree with Francesca Giommi that Abani depicts war as "an experience which [...] can hardly be described or grasped in any human language,"30 I would also contend that the writer uses My Luck's struggle with the linguistic medium as a metaphor for the character's vulnerability. Abani, once asked how his writing had helped him to reconfigure the idea of home, replied: "For me, home has always existed in language.”31 The fact that the author expressly denies his hero the privilege of this comfort zone may point to his wish to emphasize the distress of those who, unlike the artist, cannot find refuge in words and are forced to wander, fumble in the dark, in search of other ways of articulating their experience. In Song for Night, My Luck's quest for his lost companions may be viewed as an apt symbol of his sense of disorientation and of his difficult pursuit of alternative means of expression. Ironically, while the narrator finds no solace in language, the unspoken modes of communication that he develops to establish contact with Ijeoma and exchange information with his comrades are transient and destined to disappear, and they can only be retrieved by readers through the words on the page. This seems to suggest that, paradoxically, the only hope we have of transcending the limitations of language lies in language itself, and in its recording in the literary form. While literature is inherently flawed because it owes its very existence to the linguistic medium, it is nevertheless an interface - a translocation - that can gesture towards an understanding of the complex, figurative translocation-as-movement that is the transition from reality to language.

The telepathic medium that My Luck shares with Ijeoma is not his only alternative means of communication. He develops another surrogate language of sorts, which serves his urge for recovering his traumatic past. This code, likened to "Braille" (26), takes the form of

\footnotetext{
${ }^{30}$ Giommi, "Negotiating Freedom on Scarred Bodies,” 181. This article briefly discusses the importance of language in Song for Night and in Abani's entire "artistic enterprise" (181).

${ }^{31}$ Abani made this comment at the EACLALS conference "Try Freedom: Rewriting Rights in/through
} 
Published in: Postcolonial Translocations: Cultural Representation and Critical Spatial Thinking, ed. by Marga Munkelt, Markus Schmitz, Mark Stein \& Silke Stroh (Amsterdam \& New York: Rodopi, 2013), pp. 127-143.

Status: Postprint (Author's version)

small crosses that the protagonist carves on his left forearm to represent all the loved ones that he has lost and, more disturbingly, all the people that he has enjoyed killing - a collection of scars that he calls the "map of [his] consciousness" (25). Thus, the narrator's body is presented as a site of remembrance, ${ }^{32}$ but the emphasis on the character's pleasure during some of his own murderous acts prevents any romanticized interpretation of memory. In other words, My Luck’s “own personal cemetery” (38) is neither exclusively a record of unjust acts committed against innocent human beings by immoral ones, nor a reminder of the triumph of the virtuous over the despicable. By blurring the lines between innocence and guilt, the author rejects any manichaean approach to his protagonist's personality and, by extension, to the Biafran war, even if the conflict was triggered by the mass killing of Igbos by Hausas. This nuanced position is forcefully illustrated by the rhetorical question that My Luck asks toward the end of the novella: "If we are the great innocents in this war, then where did we learn all the evil we practice?” (143). Abani's thought-provoking treatment of innocence and guilt arguably exposes the flawed nature of all clear-cut judgments and, in doing so, rejects any sentimental approach to the trauma of war.

The subtlety with which the writer invites readers to reflect on his character's response to the harrowing experience of the Biafran conflict has been praised by other critics - among them Louise Bernard, who has saluted the novella’s "commit[ment] to an engaged empathy." However, according to Bernard, Abani's narrative "gives way to sentimentality at the very end," ${ }^{33}$ when My Luck is reunited with his dead mother and his voice returns. Even though the conclusion to the novella may indeed elicit an emotional response, an interpretation which reduces the ending to a ploy to bring forth unrestrained empathy on the part of the reader would overlook one of the work's most profound insights. Such an insight, I believe, arises partly from the unexpected clash between the different levels of reality established at the beginning of the narrative. As the story draws to an end and it is unambiguously revealed that the narrator has been dead all along, readers are compelled to realize that the hero's search for his platoon, a quest which they had (at least to some extent) assumed to be a translocation-asmovement situated on the 'objective' level, in fact entirely took place in an imaginary translocation. Once again, this obligation to re-assign the events recounted in the narrative to the realm of fantasy encourages readers to approach the text critically, as it forces them to acknowledge the deception upon which their emotional involvement with the character has

\footnotetext{
Postcolonial Cultures.”

${ }^{32}$ See also Giommi, "Negotiating Freedom on Scarred Bodies,” 181.

${ }^{33}$ Louise Bernard, "Silent Warrior," Washington Post (2 September 2007), www.washingtonpost.com/wp-
} 
Published in: Postcolonial Translocations: Cultural Representation and Critical Spatial Thinking, ed. by Marga Munkelt, Markus Schmitz, Mark Stein \& Silke Stroh (Amsterdam \& New York: Rodopi, 2013), pp. 127-143.

Status: Postprint (Author's version)

been based.

For those more closely acquainted with Nigerian literature, the sense of distance thereby established may be reinforced by the realization that the ending of the novella reverses the scenario found in the conclusion to Ken Saro-Wiwa's novel Sozaboy, in which the hero is mistaken for a ghost by the inhabitants of his village even though he is well and truly alive. Such possible signs of intertextuality, as Stef Craps has argued in another context, may be used by a writer to "signal his historical [...] remove from, and his inevitably mediated mode of access to, the reality he represents.” ${ }^{34}$ Admittedly, Abani does not explicitly show any willingness to subvert (or even directly address) Sozaboy, and it might be further objected that the protagonist of Song for Night is nowhere as naive as Mene, the narrator of SaroWiwa's tragicomic tale. However, the connections that may be established between the books' inverse narrative patterns inevitably make Song for Night enter into dialogue with Sozaboy. This comparison is also supported by the eerie echoes between the Molière quotation that opens Abani's novella, and the passage from Saro-Wiwa's text that I have used as my own epigraph. These potential intertextual links may encourage the reader to temporarily disengage from My Luck's personal story and more carefully consider some of the common reflections featured in the two narratives, including the chain of events that led to the devastation of countless young lives during the Biafran war.

Eschewing unrestrained sentimentality, Abani offers his character a poignant but highly ambiguous reunion with his mother. At the end of the journey that has allowed My Luck to "relive and release [his] darkness" (104), his mother hugs him and says: "You are home” (167), upon which the boy's voice returns. The association between the protagonist's homecoming and his symbolic recovery of language seems to be charged with meaning, but it does not lend itself to easy interpretation. On the one hand, the combination may be an indication of the redemptive possibilities of literature: the end of My Luck's story coincides with the end of his wandering, which may suggest that Abani's book has helped the narrator to find a home through language, and that the protagonist may now find a sense of belonging in language, as the author always has. On the other hand, My Luck's redemption of sorts, his second chance at happiness, as it were, only occurs at the moment that seals his death which, of course, does not offer a viable solution for the human race. ${ }^{35}$ Ultimately, Song for

${ }^{34}$ Stef Craps, "Linking Legacies of Loss: Traumatic Histories and Cross-Cultural Empathy in Caryl Phillips's Higher Ground and The Nature of Blood," Studies in the Novel 40.1-2 (Spring-Summer 2008): 200.

${ }^{35}$ The concept of redemption, which recurs in Abani's work, is to be understood "not in a spiritual sense, but in the sense of becoming fully human.” According to the writer, reflecting on the possibility of redemption consists 
Published in: Postcolonial Translocations: Cultural Representation and Critical Spatial Thinking, ed. by Marga Munkelt, Markus Schmitz, Mark Stein \& Silke Stroh (Amsterdam \& New York: Rodopi, 2013), pp. 127-143.

Status: Postprint (Author's version)

Night is perhaps not so much about redemption as it is about "becoming" 36 - that is, about a process which, one day, might allow human beings to become reconciled with, and perhaps move beyond, their own contradictions.

In this essay, I have attempted to unravel the literary strategies that lie at the core of Abani's humanistic project. I have examined various incarnations of translocation in Song for Night, particularly those relating to the metaphoric representation of death and to the transposition of reality into language; further, I have tried to underline the pivotal role played by these instances of translocation in the novella's development of distancing devices. What has been holding these diverse interpretative threads together is the concept of, and methodological framework around, trauma, and more specifically the belief that, despite appearances, Abani's narrative maintains a constant equilibrium between eliciting emotional involvement and triggering critical reactions - a balance characteristic of works that encourage 'empathic unsettlement'. The writer's response to the ethical challenge posed to 'secondary witnesses' of trauma is similarly discernible in the novella's ending, which promotes ambiguity rather than closure. Abani's cautious evocation of the possibility of redemption indicates that his vision is "open to the challenge of Utopian aspiration," yet arguably resists "the enigmatic call of an open or empty Utopia." ${ }^{37}$ Indulging neither in euphoria nor in despair, Abani's art maintains a glimmer of hope in the bleakest of circumstances, a position perhaps most fittingly summarized in the writer's own words:

One of my earliest spiritual advisers told me that to be human is to accept that there will never be world peace, but to live life as though it is possible. This is the core of my aesthetic: belief in a deeper humanness that is beyond race, class, gender, and power, even as I know that it is not possible. And yet I strive for it in every way, even when I fail. In the end, we may never know. Perhaps it is enough [...] to know that it will always be hard. May we cry, but may we never die of heartbreak. ${ }^{38}$

in examining "how far into darkness [...] a being [can] go and still find their way back to light." See Chris Abani, “The Truthdig Interview," by Zuade Kaufman, Truthdig (18 April 2006), www.truthdig.corn/report/itern/20060418 _chris_abani_truthdig_interview/?/interview/item/ 20060418_chris_abani_truthdig_interview (accessed 5 April 2010).

${ }^{36}$ This is another central notion in Abani's imagination, as suggested for instance by the title of his novella Becoming Abigail.

${ }^{37}$ LaCapra, Writing History, Writing Trauma, 42, 197.

38 Abani, "Ethics and Narrative," 173. 
Published in: Postcolonial Translocations: Cultural Representation and Critical Spatial Thinking, ed. by Marga Munkelt, Markus Schmitz, Mark Stein \& Silke Stroh (Amsterdam \& New York: Rodopi, 2013), pp. 127-143.

Status: Postprint (Author's version)

\section{Works Cited}

Abani, Chris. Becoming Abigail (New York: Akashic, 2006).

—. "Ethics and Narrative: The Human and Other," Witness 22 (2009), http://witness.blackmountaininstitute.org/archive/xxii/Witness_XXII-Abani.pdf (accessed 5 April 2010): 167-73.

—. Interview by Carlye Arcbibeque, Poetix (2005), http://poetix.net/abani.htm (accessed 5 April 2010).

—. Kalakuta Republic (London: Saqi, 2000).

—_. "The Model of African Wars,” Voices Education Project (nd), http://voicesinwartime.org/ content/chris-abani (accessed 5 April 2010).

—. Song for Night (New York: Akashic, 2007).

—. "The Truthdig Interview," by Zuade Kaufman, Truthdig (18 April 2006), www.truthdig.com/report/item/20060418_chris_abani_truthdig_interview/?/interview/ item/20060418_chris_abani_truthdig_interview (accessed 5 April 2010).

- The Virgin of Flames (New York: Penguin, 2007).

Adorno, Theodor. “Cultural Criticism and Society,” Prisms, tr. Samuel Weber \& Shierry Weber ("Kulturkritik und Gesellschaft," 1951; Cambridge MA : MIT Press, 1981): 17-34.

—. Negative Dialectics, tr. E.B. Ashton (Negative Dialektik, 1966; New York: Continuum, 1973).

Bernard, Louise. "Silent Warrior," Washington Post (2 September 2007), www .washingtonpost.com/wp-dyn/content/article/2007/08/30/AR2007083001619.html (accessed 5 April 2010).

Castaneda, Carlos. The Teachings of Don Juan: A Yaqui Way of Knowledge (1969: Berkeley \& Los Angeles: U of California P, 1998).

Craps, Stef. "Linking Legacies of Loss: Traumatic Histories and Cross-Cultural Empathy in Caryl Phillips's Higher Ground and The Nature of Blood,” Studies in the Novel 40.1-2 (Spring-Summer 2008): 191-202.

_ _ \& Gert Buelens. "Introduction: Postcolonial Trauma Novels,” Studies in the Novel 40.1-2 (Spring-Summer 2008): 1-12.

Giommi, Francesca. "Negotiating Freedom on Scarred Bodies,” Experiences of Freedom in Postcolonial Literatures and Cultures, ed. Annalisa Oboe \& Shaul Bassi (Abingdon \& New York: Routledge, 2011): 176-84. 
Published in: Postcolonial Translocations: Cultural Representation and Critical Spatial Thinking, ed. by Marga Munkelt, Markus Schmitz,

Mark Stein \& Silke Stroh (Amsterdam \& New York: Rodopi, 2013), pp. 127-143.

Status: Postprint (Author's version)

Gluckstern, Nicole. “Shorts,” San Francisco Bay Guardian Online (25 September 2007), www.sfbg.com/2007/09/25/shorts (accessed 5 April 2010).

Knox, Malcolm. "Haunted by the Ghosts in a Child Soldier's Life,” Sydney Morning Herald (8 November 2008), www.smh.com.au/articles/2008/ll/07/1225561105879.html (accessed 5 April 2010).

LaCapra, Dominick. Writing History, Writing Trauma (Baltimore MD: Johns Hopkins UP, 2001).

Marshall, Robert. “The Dark Legacy of Carlos Castaneda,” salon.com (4 April 2007), www.salon.com/books/feature/2007/04/12/castaneda (accessed 5 April 2010).

Molière. Le Dépit amoureux (1656), Euvres de Molière 1, ed. Eugène Despois (Paris: Hachette, 1873).

Rabalais, Kevin. “The Clarity of Distance,” Australian (30 August 2008), www.the australian.com.au/news/arts/the-clarity-of-distance/story-e6frg8n6-1111117306592 (accessed 5 April 2010).

Rothberg, Michael. “Decolonizing Trauma Studies: A Response,” Studies in the Novel 40.1-2 (2008): 224-34.

Saro-Wiwa, Ken. Sozaboy (1985; New York: Longman, 1994).

Schindler’s List, dir. Steven Spielberg. Universal, 1993.

Spivak, Gayatri Chakravorty. “Can the Subaltern Speak?” Marxism and the Interpretation of Culture, ed. Cary Nelson \& Lawrence Grossberg (Urbana \& Chicago: U of Illinois P, 1988): 271-313.

Tutuola, Amos. The Palm-Wine Drinkard (London: Faber \& Faber, 1952). 